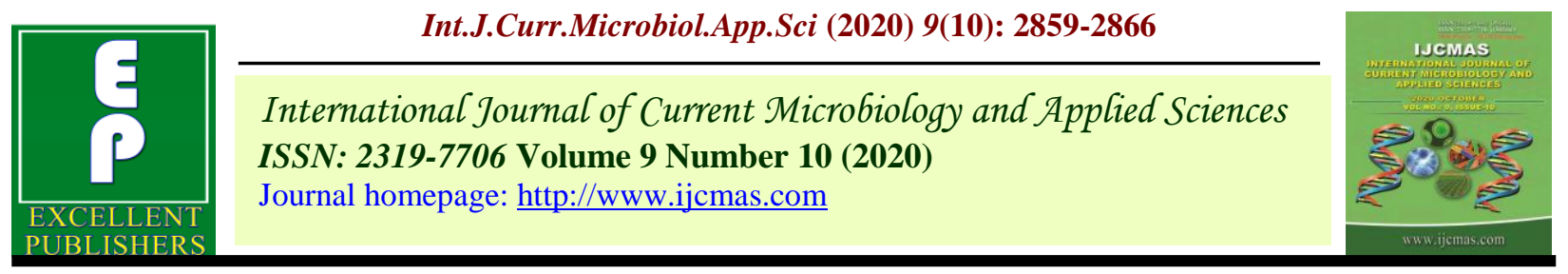

\title{
Response of Different Endophytic Bacterial Strain on Seedling Growth and their Co-inoculation on Growth and Development of Maize Plant (Zea mays L.) under Laboratory Condition and Polyhouse Condition
}

\author{
Abhilash Behera ${ }^{1,2^{*}}$, Shouvik Gorai ${ }^{1,3}$, R. K. Singh ${ }^{1}$ and M. A. Ashrutha ${ }^{1}$ \\ ${ }^{I}$ Department of Genetics and Plant Breeding, IAS, BHU, Varanasi, India \\ ${ }^{2}$ Department of Genetics and Plant Breeding, MSSSoA, Centurion University of Technology \\ and Management, Parlakhemundi, Odisha, India \\ ${ }^{3}$ Department of Genetics and Plant Breeding, BCKV, Mohanpur, Nadia, West Bengal, India \\ *Corresponding author
}

\begin{tabular}{|c|c|}
\hline & A B S T R A C T \\
\hline $\begin{array}{l}\text { K e y w o r d s } \\
\text { PGPR, Endophytic } \\
\text { bacteria, } \\
\text { Biochemical } \\
\text { parameters, Co- } \\
\text { inoculation }\end{array}$ & \multirow{3}{*}{$\begin{array}{l}\text { The experiment was carried out in both laboratory as well as poly-house condition at } \\
\text { Department of Genetics and Plant Breeding, Institute of Agricultural Sciences, Banaras } \\
\text { Hindu University Varanasi, India. Under this study, four different endophytic bacterial } \\
\text { strains namely Burkholderia cepacia (RRE3), Rhizobium leguminosarum bv. Phaseoli } \\
\text { (RRE6), Pseudomonas aeruginosa (BHU3), Pseudomonas saponiphila (BHU8) were } \\
\text { characterized for different physiological characters production of IAA, siderophore, and } \\
\text { solubilization of phosphorus, zinc, potash. The plant-microbe interaction effect of these } \\
\text { bacteria, either singly or in combination, on growth and development of maize (Malviya } \\
\text { Hybrid Maize 2) were also studied. The results reveal that the combination of BHU8 with } \\
\text { RRE3 proved to be most beneficial and efficient with regards to many of the growth } \\
\text { parameters like shoot and root length, number of leaves, shoot and root fresh weight, } \\
\text { shoot, root dry weight and chlorophyll content. }\end{array}$} \\
\hline Article Info & \\
\hline $\begin{array}{l}\text { Accepted: } \\
\text { 20 September } 2020 \\
\text { Available Online: } \\
10 \text { October } 2020\end{array}$ & \\
\hline
\end{tabular}

\section{Introduction}

Maize (Zea mays L.) is one of the most important cereal crops in the world. It is of American origin and has been domesticated about 8,000 years ago. It is an annual grass and belongs to family Poaceae. It is the only species of genus Zea $(2 \mathrm{n}=20)$ and has two close botanical relatives; gamma grass (Tripsacum, $2 \mathrm{n}=36,72$ ) and Teosinte (Euchlaena, $2 \mathrm{n}=20$ ). It has a very high yield potential. The crop is being regarded as a "Queen of Cereals" because of its carbon pathway $\left(\mathrm{C}_{4}\right)$, higher multiplication ratio, wider adaptability, desirable architecture, superior transpiration efficiency, highly versatile use, etc.

In India Karnataka, Madhya Pradesh, Bihar, Uttar Pradesh, Andhra Pradesh, Maharashtra, Gujarat and Punjab are the leading states growing maize on large scale. For its 
cultivation, maize require a large amount of nitrogen $(120 \mathrm{~kg} / \mathrm{ha})$, phosphorus $(60 \mathrm{~kg} / \mathrm{ha})$ and potassium $(60 \mathrm{~kg} / \mathrm{ha})$ as chemical fertilizer. This amounts to be very large input for the crop and farmers have to invest a huge amount of money. Annually more than 199.4 million tons of chemical fertilizer is used worldwide to increase the yield of plants. Though these chemicals have high efficiency in promoting crop yield, they have proved to be hazardous for soil health as well as of animals and human population. In current trends of agriculture, more emphasis is given to reduce the use of pesticides and inorganic fertilizer, forcing the search for alternative ways to improve crop yield in sustainable agriculture (Smith et al., 2001). Biological fertilizer is preferred over chemical fertilizer, as they are not only eco-friendly and economical in approach, but are also involved in enhancing the soil quality and maintenance of natural soil flora.

The use of microbes as bio-fertilizers and/or antagonists of phytopathogens is a tool of sustainable agriculture which provides a promising alternative to chemical fertilizers and pesticides. In recent years, the use of Plant growth promoting rhizobacteria (PGPR) for sustainable growth in agricultural productivity has increased tremendously in various parts of the world. Plant growth promoting rhizobacteria (PGPR) isa bacterial group of microorganisms which are beneficial to crops and that colonize roots or rhizosphere soil of crop plants. The term PGPR was coined by Joe Kloepper presently at Auburn University in the United States in the later part of the 1980s. these bacteria associates with root surface of host plant and in general produce the beneficial effect through established mechanisms on host plants.

The exact mechanism by which PGPR promote plant grow this not completely understood but those which were identified include (i) the ability to produce or change the concentration of plant growth regulators like indole acetic acid (IAA), gibberellic acid, cytokinins and ethylene (Arshad and Frankenberger, 1991) (ii) biological $\mathrm{N}_{2}$ fixation (Boddey and Dobereiner, 1995) (iii) antagonism against phytopathogenic microorganisms by production of siderophores (Scher and Baker, 2006), antibiotics and cyanide (Flaishman et al., 2001) (iv) solubilization of mineral phosphates and other nutrients (DeFreitas et $a l ., 2007)$ and reducing the abiotic stresses. Unfortunately, the interaction between associative PGPR and plants may be unstable and gives variable results. The good results obtained in-vitro cannot always be reproduced underfield conditions (Chanway and Holl, 1993; Zhender et al., 1999).

\section{Treatment details}

It include the four PGPR strains, i.e., Burkholderia cepacia (RRE3), Rhizobium leguminosarum bv. Phaseoli (RRE6), Pseudomonas aeruginosa (BHU3)and Pseudomonas saponiphila (BHU8) were selected for this study on the basis of their earlier performance. The endophytic bacterial strains were used alone as well as in all combinations. Along with these uninoculated water-soaked seeds (without bacterial inoculation) is used as control which is considered for comparing the effectiveness of the treatments.

\section{Response of different endophytic bacterial strain under the laboratory condition}

To study the effect of inoculation with different endophytic rhizobacterial strains on germination criteria and other plant growth parameter on maize plant, plant infection test was performed in Gibson's tubes (38 X 200 $\mathrm{mm}$ ) having agar slants containing nitrogen free Fahraeus medium. 


\section{Seedling shoot length}

Shoot length was measured from stem base of the emerging root to the tip of the fully expanded leaf. The height of seedlings was recorded after 12 days of inoculation of endophytic bacteria. A significant increase in the shoot length was recorded in all bacterial inoculation. However, RRE3 $\times$ BHU8 combination strain show maximum increase $(111.48 \%)$ in seedling shoot length followed by RRE3 $\times$ BHU3 combination (102.46\%), RRE6 $\times$ BHU3 combination (98.77\%), RRE6 $\times$ BHU8 combination (78.69\%) in Fig. 1. A minimum increase $(49.18 \%)$ was observed in RRE3 over non-treated control (Table 1).

The strain BHU8 in combination with RRE3 gave the best interaction response for shoot length of the seedling (111.48\%) over the uninoculated control, which is parallel to the result of Marques et al., (2010), that 1C2 strain of Ralstonia eutropha enhances shoot length by $24 \%$ and plant biomass by $100 \%$ thereby increasing plant growth and nutrition. A similar result was obtained by Dobbelaere et al., (2002) who estimated the inoculation effect of PGPR Azospirillum brasilense on growth of spring wheat. They observed a better germination, early development and flowering and also increase in dry weight of both the root system and the upper plant parts in the inoculated plants.

\section{Seedling Root length}

Root length was measured from the base of the stem to the end of root tip and values. After 12 days of sowing, the plant was uprooted with care to avoid damage to roots and washed with sterile water. Root length was significantly increased in maize cultivar after inoculation with all the endophytic bacterial strain. Maximum increase $(139.68 \%)$ in root length of seedling was observed in RRE3 $\times$ BHU 8 combination strain; whereas plant inoculated with BHU8 strain show a minimum increase $(61.11 \%)$ over nontreated control plant (Table 1) (Fig. 2). The selected strains were inoculated alone and in different combinations on maize (Malviya Hybrid Maize 2) seeds and their effect were studied under laboratory conditions.

The strain BHU8 in combination with RRE3 gave the best interaction response for root length $(139.68 \%)$ over the uninoculated control, which is parallel to the result of Marques et al., (2010), that 1C2 strain of Ralstonia eutropha enhances shoot length by $24 \%$ and plant biomass by $100 \%$ thereby increasing plant growth and nutrition.

A similar result was obtained by Dobbelaere et al., (2002) who estimated the inoculation effect of PGPR Azospirillum brasilense on growth of spring wheat. They observed a better germination, early development and flowering and also increase in dry weight of both the root system and the upper plant parts in the inoculated plants.

\section{Response of different endophytic bacterial strain on growth and development of maize plant under the poly-house condition}

\section{Shoot length}

It was measured from stem base of the emerging root to the tip of the fully expanded leaf. Plant height was recorded after 60 days of inoculation of endophytic bacteria. A significant increase in the shoot length was observed in all the bacterial treatments over control. However maximum shoot length was recorded in the RRE3 $\times$ BHU8 combination $(67.18 \%)$ followed by RRE3 $\times$ BHU3 combination $(54.54 \%)$ whereas the strain RRE3 (33.25\%) showed a minimum increase in the shoot length over non-treated control (Table 2). 


\section{Root length}

Root length was measured from the base of the stem to the end of root tip. After uprooting the plants, roots were thoroughly washed and its length was measured. As far as root length is concerned, it was observed that combination RRE3 $\times$ BHU8 showed maximum elongation in root length (101.28\%) and Fig.3 whereas minimum root length was recorded in maize plant inoculated with BHU8 (44.67\%) when compared to other bacterial treatment over non-treated control (Table 2).

\section{Chlorophyll content}

Chlorophyll content (CCI reading) of the upper two fully expanded leaves was measured by using CCM-200 plus Chlorophyll Content Meter. The chlorophyll content was recorded after 45 days of sowing using CCM-200 plus Chlorophyll Content
Meter. The data on chlorophyll content index (CCI) indicate that a significant improvement in CCI was recorded when the maize plants were inoculated with RRE6 $\times$ BHU3 combination (150.74\%) followed by RRE3 $\times$ BHU 8 combination (134.73\%) whereas a minimum increase in chlorophyll content was observed in case of RRE3 $(71.00 \%)$ over non-treated control (Table 2).

\section{Number of leaves}

Number of leaves was recorded by counting after 45 days of sowing. Maize plant inoculated with RRE3 $\times$ BHU8 combination strain show maximum increase $(38.24 \%)$ on the number of leaves; whereas a minimum increase $(17.65 \%)$ was observed in RRE3 $\times$ BHU3combination(Table 2). Gholami et al., (2012) reported an increased leaf by $72 \%$ when maize plant was inoculated with Azotobacter $\mathrm{s}-5+$ Azospirillum s-21( $\left(\mathrm{A}_{1} \mathrm{Z}_{1}\right)$.

Table.1 Effect of inoculation of endophytic bacteria on seedling growth promotion of maize under laboratory condition

\begin{tabular}{|l|c|c|}
\hline Bacterial Strain & Seedling Shoot Length & Seedling Root Length \\
\hline Control (Uninoculated) & 8.13 & 4.20 \\
\hline BHU3 & $12.93^{*}$ & $8.53^{*}$ \\
& $(59.02)$ & $(103.17)$ \\
\hline BHU8 & $12.40^{*}$ & $6.77^{*}$ \\
& $(52.46)$ & $(61.11)$ \\
\hline RRE3 & $12.13^{*}$ & $7.53^{*}$ \\
& $(49.18)$ & $(79.37)$ \\
\hline RRE6 & $14.27^{*}$ & $8.97^{*}$ \\
& $(75.41)$ & $(113.49)$ \\
\hline RRE3+BHU8 & $16.47^{*}$ & $9.87^{*}$ \\
& $(102.46)$ & $(134.92)$ \\
\hline RRE6+BHU3 & $17.20^{*}$ & $10.07^{*}$ \\
& $(11.48)$ & $(139.68)$ \\
\hline RRE6+BHU8 & $16.17^{*}$ & $9.57^{*}$ \\
& $(98.77)$ & $(127.78)$ \\
\hline CD at 1\% & $14.53^{*}$ & $9.33^{*}$ \\
\hline SEM \pm & $(78.69)$ & $(122.22)$ \\
\hline
\end{tabular}

Values in parenthesis indicate \% increase over control 
Table.2 Effect of inoculation of endophytic bacteria on plant growth promotion of maize under poly house condition

\begin{tabular}{|c|c|c|c|c|c|c|c|c|}
\hline \multirow[t]{2}{*}{$\begin{array}{l}\text { Bacterial } \\
\text { Strains }\end{array}$} & \multirow{2}{*}{$\begin{array}{c}\text { Chlorophyll } \\
\text { Content } \\
\text { Index } \\
\text { (CCI) }\end{array}$} & \multirow{2}{*}{$\begin{array}{c}\text { No of } \\
\text { Functional } \\
\text { Leaves } \\
\text { Plant }^{-1}\end{array}$} & \multirow{2}{*}{$\begin{array}{c}\text { Shoot } \\
\text { Length } \\
\text { (cm) }\end{array}$} & \multirow{2}{*}{$\begin{array}{c}\text { Root } \\
\text { Length } \\
\text { (cm) }\end{array}$} & \multicolumn{2}{|c|}{$\begin{array}{l}\text { Fresh Weight } \\
\text { Plant }^{-1}\left(\text { gm }^{2}\right)\end{array}$} & \multicolumn{2}{|c|}{$\begin{array}{l}\text { Dry Weight } \\
\text { Plant }^{1} \text { (gm) }\end{array}$} \\
\hline & & & & & Shoot & Root & Shoot & Root \\
\hline $\begin{array}{l}\text { Control } \\
\text { (Uninoculated) }\end{array}$ & 5.18 & 5.67 & 36.80 & 27.60 & 20.07 & 20.51 & 2.33 & 4.09 \\
\hline BHU3 & $\begin{array}{c}9.94 * \\
(91.70)\end{array}$ & $\begin{array}{c}6.83 * \\
(20.59)\end{array}$ & $\begin{array}{l}51.97 * \\
(41.24)\end{array}$ & $\begin{array}{l}47.18 * \\
(70.95)\end{array}$ & $\begin{array}{l}27.92 * \\
(39.10)\end{array}$ & $\begin{array}{l}28.80 * \\
(40.44)\end{array}$ & $\begin{array}{c}4.06^{*} \\
(74.36)\end{array}$ & $\begin{array}{c}7.15^{*} \\
(75.04)\end{array}$ \\
\hline BHU8 & $\begin{array}{c}9.27 * \\
(78.78)\end{array}$ & $\begin{array}{c}7.00 * \\
(23.53)\end{array}$ & $\begin{array}{l}50.76 * \\
(37.94)\end{array}$ & $\begin{array}{l}39.93 * \\
(44.67)\end{array}$ & $\begin{array}{l}27.14 * \\
(35.21)\end{array}$ & $\begin{array}{l}28.58 * \\
(39.33)\end{array}$ & $\begin{array}{c}3.73 * \\
(60.46)\end{array}$ & $\begin{array}{c}6.12 * \\
(49.67)\end{array}$ \\
\hline RRE3 & $\begin{array}{c}8.86^{*} \\
(71.00)\end{array}$ & $\begin{array}{c}7.00 * \\
(23.53)\end{array}$ & $\begin{array}{l}49.03^{*} \\
(33.25)\end{array}$ & $\begin{array}{l}43.07 * \\
(56.05)\end{array}$ & $\begin{array}{l}26.81^{*} \\
(33.58)\end{array}$ & $\begin{array}{l}29.16^{*} \\
(42.16)\end{array}$ & $\begin{array}{c}3.58^{*} \\
(53.87)\end{array}$ & $\begin{array}{c}6.66^{*} \\
(62.97)\end{array}$ \\
\hline RRE6 & $\begin{array}{c}9.89 * \\
(90.74)\end{array}$ & $\begin{array}{c}7.33 * \\
(29.41)\end{array}$ & $\begin{array}{l}53.30 * \\
(44.85)\end{array}$ & $\begin{array}{l}48.57 * \\
(75.98)\end{array}$ & $\begin{array}{l}28.07 * \\
(39.86)\end{array}$ & $\begin{array}{l}30.70 * \\
(49.70)\end{array}$ & $\begin{array}{c}4.28 * \\
(83.81)\end{array}$ & $\begin{array}{c}7.59 * \\
(85.64)\end{array}$ \\
\hline RRE3+BHU3 & $\begin{array}{l}10.03 * \\
(93.44)\end{array}$ & $\begin{array}{c}6.67 * \\
(17.65)\end{array}$ & $\begin{array}{l}56.87 * \\
(54.54)\end{array}$ & $\begin{array}{l}49.17 * \\
(78.14)\end{array}$ & $\begin{array}{l}36.13 * \\
(80.00)\end{array}$ & $\begin{array}{l}37.73 * \\
(83.98)\end{array}$ & $\begin{array}{c}5.09 * \\
(118.62)\end{array}$ & $\begin{array}{c}11.12 * \\
(172.02)\end{array}$ \\
\hline RRE3+BHU8 & $\begin{array}{c}12.17 * \\
(134.73)\end{array}$ & $\begin{array}{c}7.83^{*} \\
(38.24)\end{array}$ & $\begin{array}{l}61.52 * \\
(67.18)\end{array}$ & $\begin{array}{c}55.55^{*} \\
(101.28)\end{array}$ & $\begin{array}{l}38.73 * \\
(92.97)\end{array}$ & $\begin{array}{c}41.47 * \\
(102.19)\end{array}$ & $\begin{array}{c}5.98 * \\
(157.16)\end{array}$ & $\begin{array}{c}12.32 * \\
(201.39)\end{array}$ \\
\hline RRE6+BHU3 & $\begin{array}{c}13.00^{*} \\
(150.74)\end{array}$ & $\begin{array}{c}7.00 * \\
(23.53)\end{array}$ & $\begin{array}{l}55.04 * \\
(49.57)\end{array}$ & $\begin{array}{l}45.25^{*} \\
(63.95)\end{array}$ & $\begin{array}{l}35.82 * \\
(78.48)\end{array}$ & $\begin{array}{l}35.57 * \\
(73.43)\end{array}$ & $\begin{array}{c}4.67 * \\
(100.86)\end{array}$ & $\begin{array}{c}9.58 * \\
(134.50)\end{array}$ \\
\hline RRE6+BHU8 & $\begin{array}{c}10.69 * \\
(106.24)\end{array}$ & $\begin{array}{c}6.83 * \\
(20.59)\end{array}$ & $\begin{array}{l}53.68 * \\
(45.89)\end{array}$ & $\begin{array}{l}43.93 * \\
(59.17)\end{array}$ & $\begin{array}{l}33.64 * \\
(67.60)\end{array}$ & $\begin{array}{l}35.79 * \\
(74.48)\end{array}$ & $\begin{array}{c}4.51 * \\
(93.70)\end{array}$ & $\begin{array}{c}9.25 * \\
(126.26)\end{array}$ \\
\hline $\mathrm{CD}$ at $5 \%$ & 2.07 & 0.76 & 10.21 & 9.58 & 5.37 & 6.67 & 1.04 & 1.68 \\
\hline SEM \pm & 0.69 & 0.25 & 3.40 & 3.20 & 1.79 & 2.22 & 0.34 & 0.56 \\
\hline
\end{tabular}

*Values in parenthesis indicate \% increase over control

Fig.1 Effect of different endophytic bacterial strains on shoot length of maize under laboratory condition

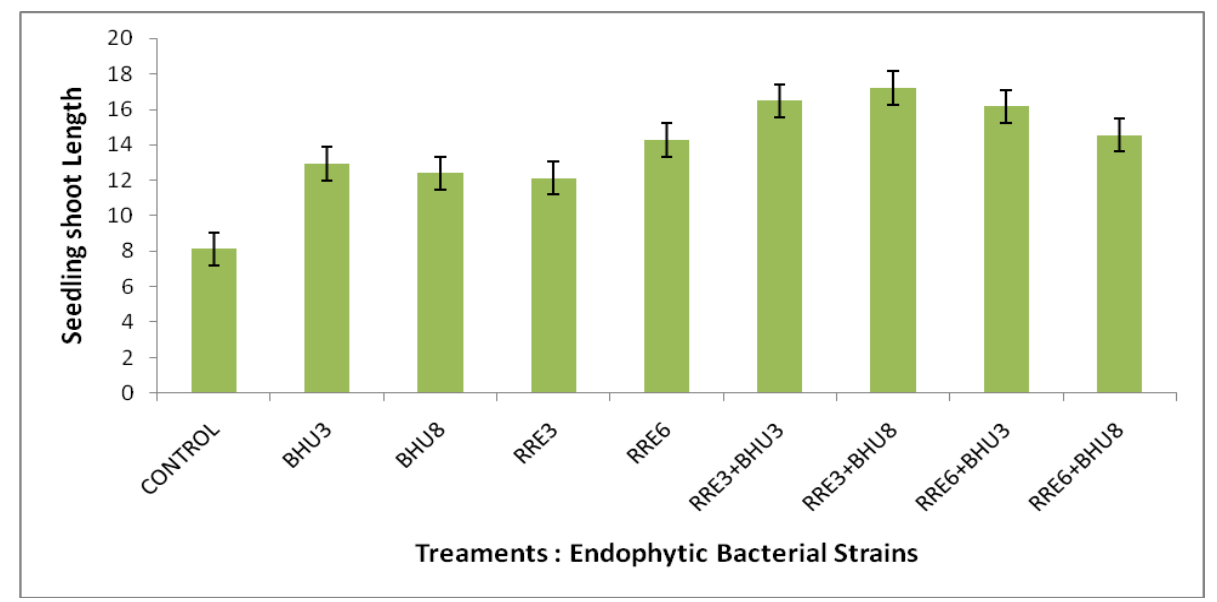


Fig.2 Effect of different endophytic bacterial strains on root length of maize under laboratory condition

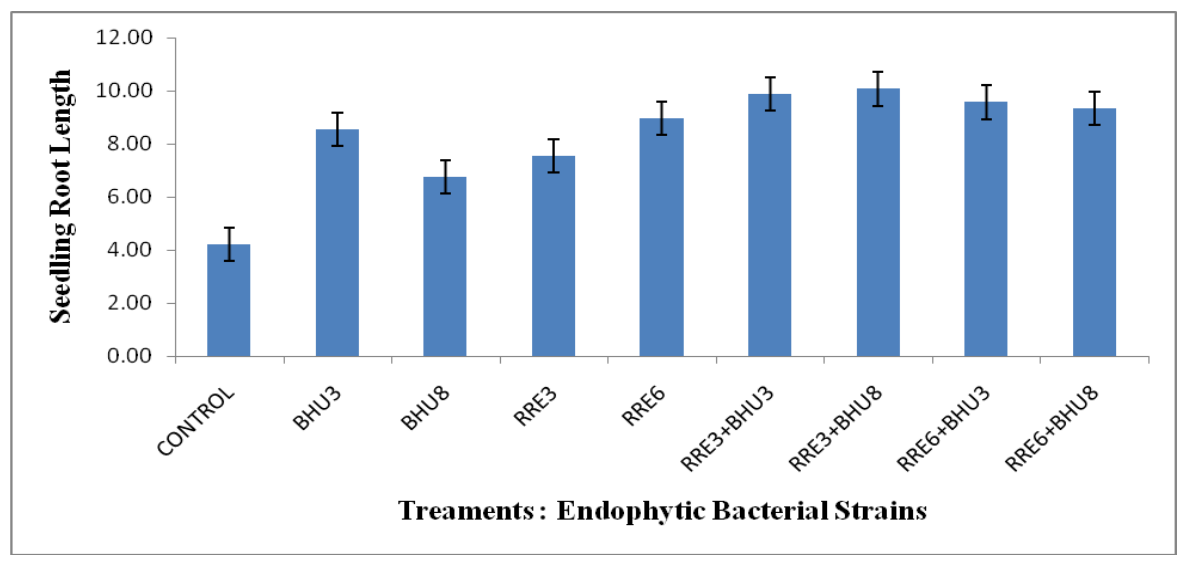

Fig.3 Effect of different endophytic bacterial strains on root length of maize under poly-house condition

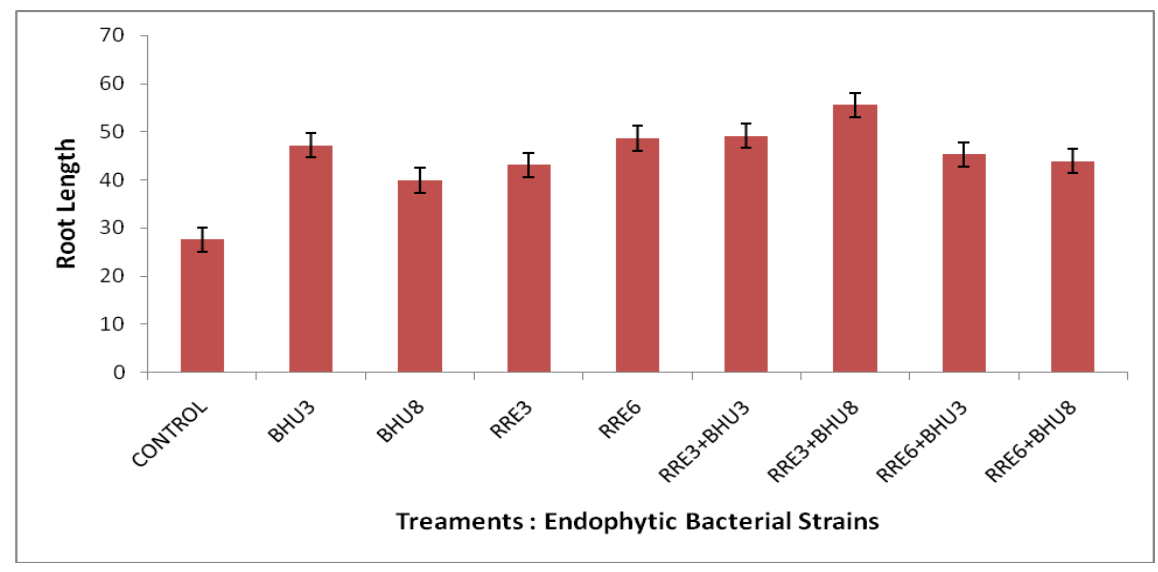

Fig.4 Effect of different endophytic bacterial strains on shoot dry weight of maize under polyhouse condition

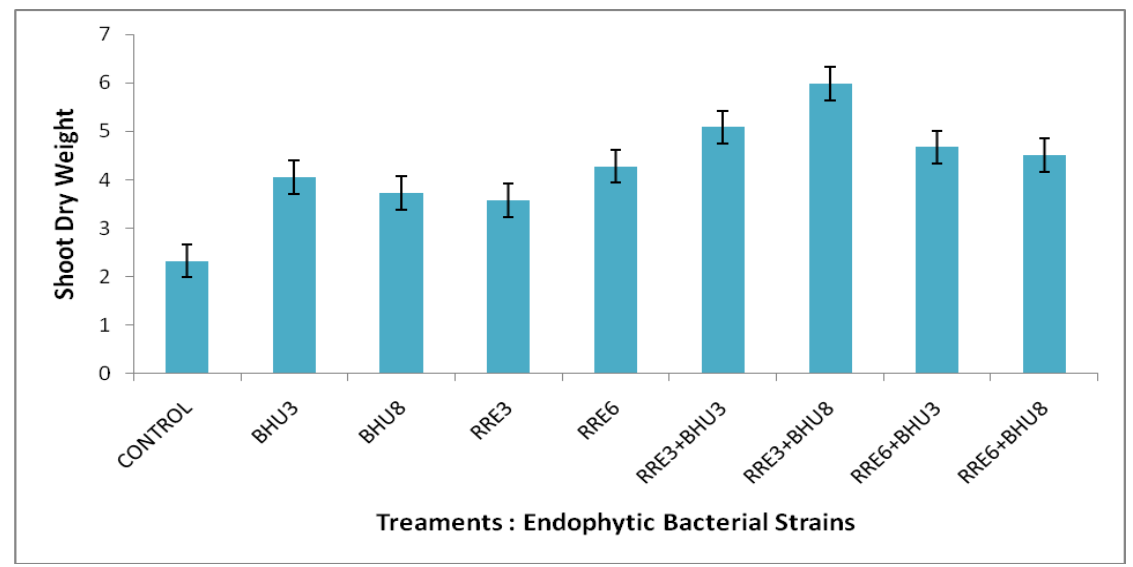




\section{Shoot fresh weight}

Immediately after harvesting plants were cut from stem base. Shoot of the plant was weighed separately using electric weighing balance \pm $0.001 \mathrm{gm}$. A significant increase in shoot fresh weight was recorded in plants inoculated with RRE3 $\times$ BHU8 combination strain $(92.97 \%)$ followed by RRE3 $\times$ BHU3 combination $(80.00 \%)$. Maize plants inoculated with RRE3 bacterial strain $(33.58 \%)$ showed a minimum increase in shoot fresh weight content when compared to other bacterial treatment over nontreated control (Table 2).

\section{Root fresh weight}

Immediately after harvesting plants were cut from stem base. Root of the plant was weighed separately using electric weighing balance \pm $0.001 \mathrm{gm}$. The maize plants inoculated with RRE3 $\times$ BHU8 combination strain show maximum root fresh weight (102.19\%) followed by RRE3 $\times$ BHU3 combination $(83.98 \%)$ over non-treated control.

A minimum increase in root fresh weight was observed in case of BHU8 (39.33\%) over the control as compared to other bacterial strain (Table 2).A similar result was obtained by Gamalero et al., (2004) who reported that coinoculation with Pseudomonas fluorescens $92 \mathrm{rk}$ and Glomusmosseae BEG12 resulted in a synergistic effect on root fresh weight and phosphorus accumulation.

\section{Shoot dry weight}

Plant samples were dried in an oven at $80^{\circ} \mathrm{C}$ for 48-72 hours to get a constant weight. Dry matter of shoot of the plants was recorded and values were expressed in grams. A significant increase in plant shoot biomass was recorded when plants were inoculated with endophytic bacterial strains. Maximum increase in shoot biomass (157.16\%) was recorded when the maize plant was inoculated with RRE3 3 BHU8 combination; whereas the minimum increase was recorded in strain RRE3 (53.87\%) over non-treated control (Table 6). Gholami et al., (2012) reported an increased stem dry weights by $84 \%$ when maize plant was inoculated with Azotobacter s-5 + Azospirillum s-21( $\left(\mathrm{A}_{1} \mathrm{Z}_{1}\right)$ (Fig. 4).

\section{Root dry weight}

Plant samples were dried in an oven at $80^{\circ} \mathrm{C}$ for 48-72 hours to get a constant weight. Dry matter of root of the plants was recorded and values were expressed in grams. A significant increase in root dry weight was exhibited by all the bacterial endophytes and their combinations. The best performance for root dry weight was shown by RRE3 $\times$ BHU8 combination (201.39\%) followed by RRE3 $\times$ BHU3 combination $(172.02 \%)$; whereas strain BHU8 show a minimum increase $(49.67 \%)$ over nontreated control (Table 2).

In conclusion the present study interaction effect of endophytic bacteria alone and their coinoculation on growth and development of maize was recorded. The interaction of BHU8 with RRE3 proved to be highly beneficial and efficient with regards to most of the growth parameters.

Various characters like plant height, root length, number of leaves, chlorophyll content, shoot and root fresh weight, shoot and root dry weight were evaluated and were found to be significantly increased over control. RRE3 $\times$ BHU8 combination showed the best performance and was recorded for increased shoot length $(67.18 \%)$, root length $(101.28 \%)$, number of leaves (38.24\%), shoot fresh weight $(92.97 \%)$, root fresh weight $(102.19 \%)$, shoot dry weight $(157.16 \%)$, root dry weight $(201.39 \%)$ over uninoculated control. Maximum chlorophyll content was recorded in the maize plant inoculated with RRE6 $\times$ BHU3 combination $(150.74 \%)$ strain over uninoculated control.

The PGPR enhances plant growth mainly through various direct and indirect effects. So, their co-inoculation was found to be most 
efficient plant growth promoter for the maize cultivar Malviya Hybrid Maize 2. Strain RRE3 was a representative of Burkholderia cepacia which belongs to beta subclass of proteobacteria while strain BHU8 was a representative of Pseudomonas saponiphila which belongs to gamma subclass of proteobacteria. The combination of these two isolates gave the best response on overall promotion of growth of maize plant and therefore it is recommended as a biofertilizer for their commercial exploitation in field trials.

\section{References}

Arshad, M., and Frankenberger, W. T. (1991). Microbial production of plant hormones. In The rhizosphere and plant growth, 327-334.

Boddey, R. M., and Dobereiner, J. (1995). Nitrogen fixation associated with grasses and cereals: recent progress and perspectives for the future. In Nitrogen Economy in Tropical Soils, 241-250.

Chanway, C. P., and Holl, F. B. (1993). First year field performance of spruce seedlings inoculated with plant growth promoting rhizobacteria. Canadian Journal of Microbiology, 39(11), 10841088.

De Freitas, J. R., Banerjee, M. R., and Germida, J. J. (1997). Phosphate-solubilizing rhizobacteria enhance the growth and yield but not phosphorus uptake of canola (Brassica napus L.). Biology and Fertility of Soils, 24(4), 358-364.

Dobbelaere, S., Croonenborghs, A., Thys, A., Ptacek, D., Okon, Y., and Vanderleyden, J. (2002). Effect of inoculation with wild type Azospirillum brasilense and $A$. irakense strains on development and nitrogen uptake of spring wheat and grain maize. Biology and Fertility of Soils, 36(4), 284-297.

Flaishman, M. A., Eyal, Z., Zilberstein, A., Voisard, C., and Haas, D. (1996). Suppression of Septoria tritici blotch and leaf rust of wheat by recombinant cyanide-producing strains of Pseudomonas putida. MPMI-Molecular Plant Microbe Interactions, 9(7), 642645.

Gholami, A., Biyari, A., Gholipoor, M., and AsadiRahmani, H. (2012). Growth promotion of maize (Zea mays L.) by plant-growth-promoting rhizobacteria under field conditions. Communications in soil science and plant analysis, 43(9), 1263-1272.

Scher, F. M., and Baker, R. (1982). Effect of Pseudomonas putida and a synthetic iron chelator on induction of soil suppressiveness to Fusarium wilt pathogens. Phytopathology, 72(12), 1567-1573.

Smit, E., Leeflang, P., Gommans, S., van den Broek, J., van Mil, S., and Wernars, K. (2001). Diversity and seasonal fluctuations of the dominant members of the bacterial soil community in a wheat field as determined by cultivation and molecular methods. Applied and Environmental Microbiology,67(5), 2284-2291.

Zehnder, G. W., Yao, C., Murphy, J. F., Sikora, E. R., Kloepper, J. W., Schuster, D. J., and Polston, J. E. (1999). Microbeinduced resistance against pathogens and herbivores: evidence of effectiveness in agriculture. Induced plant defenses against pathogens and herbivores: Biochemistry, ecology and agriculture, 33.

\section{How to cite this article:}

Abhilash Behera, Shouvik Gorai, R. K. Singh and Ashrutha, M. A. 2020. Response of Different Endophytic Bacterial Strain on Seedling Growth and their Co-inoculation on Growth and Development of Maize Plant (Zea mays L.) under Laboratory Condition and Polyhouse Condition. Int.J.Curr.Microbiol.App.Sci. 9(10): 2859-2866. doi: https://doi.org/10.20546/ijcmas.2020.910.344 